\title{
AMH: Could It Be Used as A Biomarker for Fertility and Superovulation in Domestic Animals?
}

\author{
Saqib Umer ${ }^{1,+} \oplus$, Shan Jiang Zhao ${ }^{1,+}{ }^{1}$ Abdul Sammad ${ }^{2}\left(\mathbb{D}\right.$, Bahlibi Weldegebriall Sahlu ${ }^{1}(\mathbb{D}$, \\ YunWei Pang ${ }^{1}$ (D) and Huabin Zhu ${ }^{1, *}$ \\ 1 Embryo Biotechnology and Reproduction Laboratory, Institute of Animal Sciences, Chinese Academy of \\ Agricultural Sciences, Beijing 100193, China; saqibumar33@hotmail.com (S.U.); \\ zhaoshanjiang@caas.cn (S.J.Z.); blenbah@gmail.com (B.W.S.); pangyunwei@caas.cn (Y.P.) \\ 2 Key Laboratory of Animal Genetics, Breeding and Reproduction, CAST, China Agricultural University, \\ Beijing 100193, China; drabdulsammad1742@yahoo.com \\ * Correspondence: zhuhuabin@caas.cn; Tel./Fax: +86-010-62895971 \\ + These authors contributed equally to this work.
}

Received: 8 October 2019; Accepted: 27 November 2019; Published: 4 December 2019

check for updates

\begin{abstract}
Anti-Müllerian hormone (AMH) is a reliable and easily detectable reproductive marker for the fertility competence of many farm animal species. AMH is also a good predictor of superovulation in cattle, sheep, and mares. In this review, we have summarized the recent findings related to $\mathrm{AMH}$ and its predictive reliability related to fertility and superovulation in domestic animals, especially in cattle. We focused on: (1) the dynamics of AMH level from infancy to prepubescence as well as during puberty and adulthood; (2) $\mathrm{AMH}$ as a predictor of fertility; (3) the association between antral follicle count (AFC) and plasma AMH level; (4) AMH as a predictor of superovulation; and (5) factors affecting AMH levels in domestic animals, especially cattle. Many factors affect the circulatory levels of AMH when considering the plasma, like nutrition, activity of granulosa cells, disease state and endocrine disruptions during fetal life. Briefly, we concluded that AMH concentrations are static within individuals, and collection of a single dose of blood has become more popular in the field of assisted reproductive technologies (ART). It may act as a potential predictor of fertility, superovulation, and ovarian disorders in domestic animals. However, due to the limited research in domestic animals, this potential of AMH remains underutilized.
\end{abstract}

Keywords: AMH; AFC; superovulation; fertility; domestic animals

\section{Introduction}

Anti-Müllerian hormone (AMH) has a long history, but its presence was recognized after the mid-20th century. Alfred Jost was the first to introduce the existence of AMH in 1953. At that time, scientists thought that testicular tissues not only synthesize testosterone, the chemical messenger responsible for the development of male external genitalia, but also produce a chemical that regressed Müllerian ducts in rabbit fetuses [1]. AMH was later characterized by Picon [2] and then purified from the incubation media of bovine fetal testicular tissue [3]. In late fetal life, $\mathrm{AMH}$ is secreted by ovarian granulosa cells of females (in women [4], cattle [5], and sheep [6]), when Müllerian ducts are no longer responsive to the hormone $[7,8]$. AMH is a member of the transforming growth factor beta (TGF- $\beta$ ) family and is also called Müllerian inhibiting substance/factor (MIS) [9]. It is a glycoprotein in nature, with a molecular weight of $140 \mathrm{kDa}$ corresponding to 553-575 amino acids [10] and a half-life of 1.5 days [11]. The $A M H$ gene has been mapped to chromosome 7 in cattle, mares, and goats; chromosome 5 in sheep; chromosome 9 in buffalo; and chromosome 2 in pig [12,13]. Recently, $\mathrm{AMH}$ has become a potential reproductive biomarker for predicting the ovarian pool of follicles in 
donor cows [14]. Hence, this review mainly highlights the importance of AMH as a fertility and superovulation biomarker in domestic animal species, especially in cattle.

\section{Anti-Müllerian Hormone Signaling Pathways}

The superfamily TGF- $\beta$ has over 30 ligands, including bone morphogenetic proteins (BMPs), which are the largest subfamily, as well as growth and differentiation factors (GDFs) $[15,16]$. Previously, AMH was considered as an indirect member of the TGF- $\beta$ superfamily but due to the analogy with the signaling mechanism of BMPs, however, it is now considered a direct member of this family [17]. The TGF- $\beta$ family members act through two types of heteromeric receptors (type I and type II), which further consist of two subtypes, i.e., serine and threonine. Sometimes, the co-receptors beta glycan and endoglin also help during signaling $[15,16]$. After ligand binding results, type II receptor-mediated phosphorylation takes place, activating the type I receptor that ultimately leads to the activation of several pathways, e.g., Smad, mitogen-activated protein kinases (MAPK), and phosphatidylinositol 3-kinase (PI3K)/Akt. Through the activation of Smad4, the AMH target gene regulates transcription $[15,16,18,19]$. The schematic mechanism of AMH signaling is illustrated in Figure 1.

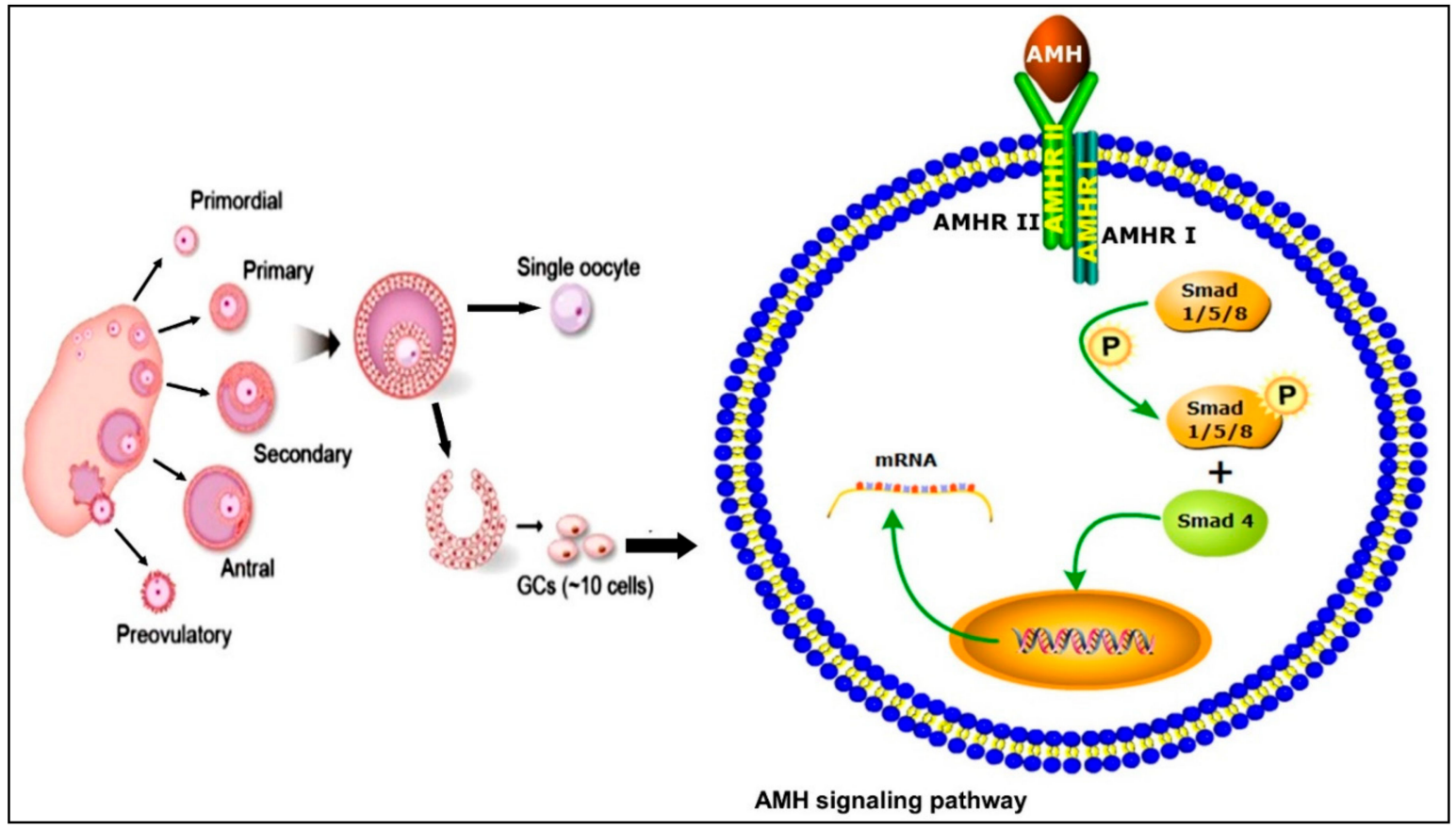

Figure 1. Schematic representation of different stages of ovarian follicular development and the anti-Müllerian hormone (AMH) signaling mechanism in granulosa cells (GCs). Upon ligand binding, the type II receptor activates the type I receptor which, in turn, activates the phosphorylation of Smads. These receptor-activated Smads interact with Smad4 and translocate to the nucleus to regulate gene transcription. 
In mammals, five different type II receptors have already been identified, with AMHRII specifically involved in AMH signaling $[17,20]$ while three BMPs (ActRII, ActRIIB, and BMPRII) were found to be involved in other signaling pathways [21]. Similarly, seven subtypes of type I receptors have also been identified in mammals (anaplastic lymphoma kinase (ALK)1-7) [21]. Among these, ALK2, ALK3, and ALK6 perform functions related to AMH [17]. Different types of BMPs are produced in different cells of the ovary and each perform their unique respective functions; BMP4 and BMP7 are expressed in theca cells [22,23] while AMH, BMP2, and BMP6 are produced in granulosa cells [24]. In goats, BMP15 regulates AMH by triggering the MAPK pathway [25]. However, owing to the fact that the signaling pathways perform complex and distinct functions in the ovary, detailed studies are required for a better understanding of ligand and receptor expression as well as the interaction and communication of binding proteins with the surrounding cells.

\section{Role of AMH}

AMH production starts as early as the initial selection of ovarian follicular waves [26]. AMH expression reaches its peak level in primordial, primary, and secondary follicles, whereas it decreases once the dominant follicle is selected and is absent in atretic follicles. This dynamic expression was firstly reported in rabbits (rodents) [27], and then in women [28], cattle [29], sheep [30], buffalo [31], goats [32], mares [33], and pigs [34]. Following ovulation in pigs, AMH expression then continues in the luteal cells of corpus luteum. The exact physiological function in luteal cells remains unknown, but it is speculated that it might be to regulate the cyclic recruitment of small antral follicles by avoiding premature exhaustion of the ovarian follicular reserves [34]. AMH controls the number of follicles and selection of the dominant follicle during follicular waves. The recruitment of follicles is faster in the absence of $\mathrm{AMH}$, but the ovarian follicular reserves exhaust at a younger age [35]. AMH has been identified to suppress follicle-stimulating hormone (FSH) receptors in gonadotropin-dependent small antral follicles [36]. In growing follicles, the FSH sensitivity of granulosa cells was reduced in the presence of AMH [37]. In the presence of luteinizing hormone (LH), thecal cells produce androgens and are transformed into estrogen by the aromatase system of granulosa cells. This process of theca and granulosa cells happens under the influence of FSH. Growing follicles with theca cells have the potential to synthesize androgens, but few of them possess the aromatase system in granulosa cells. Therefore, the possession of the aromatase system is under the control of FSH in granulosa cells with more FSH receptors, leading to a high proliferation of granulosa cells which ultimately selects and precedes the dominant follicle [38]. In another study, De Clemente et al. proposed a regulatory role for $\mathrm{AMH}$ on follicular development and maturation. AMH retards the expression of the aromatase enzyme and suppression of the LH receptor on the surface of granulosa cells [39], representing a renowned phenomenon in which meiotic division is arrested at prophase I, during oogenesis, and is physiologically resumed after females have undergone puberty [40]. In rat oocytes, germinal vesicle breakdown (GVBD) was inhibited by AMH during in vitro experiments [41]. Furthermore, both in vivo and in vitro experiments in mice have shown that AMH also inhibits FSH superstimulated follicular growth [36]. As shown in Figure 2, AMH plays two critical functional roles in females: 1) it inhibits primordial follicular growth from the ovarian follicular pool by avoiding premature exhaustion of the follicular reserves of the female, and 2) it reduces the sensitivity of the preantral and small antral follicles to FSH while modulating follicular development [42]. 


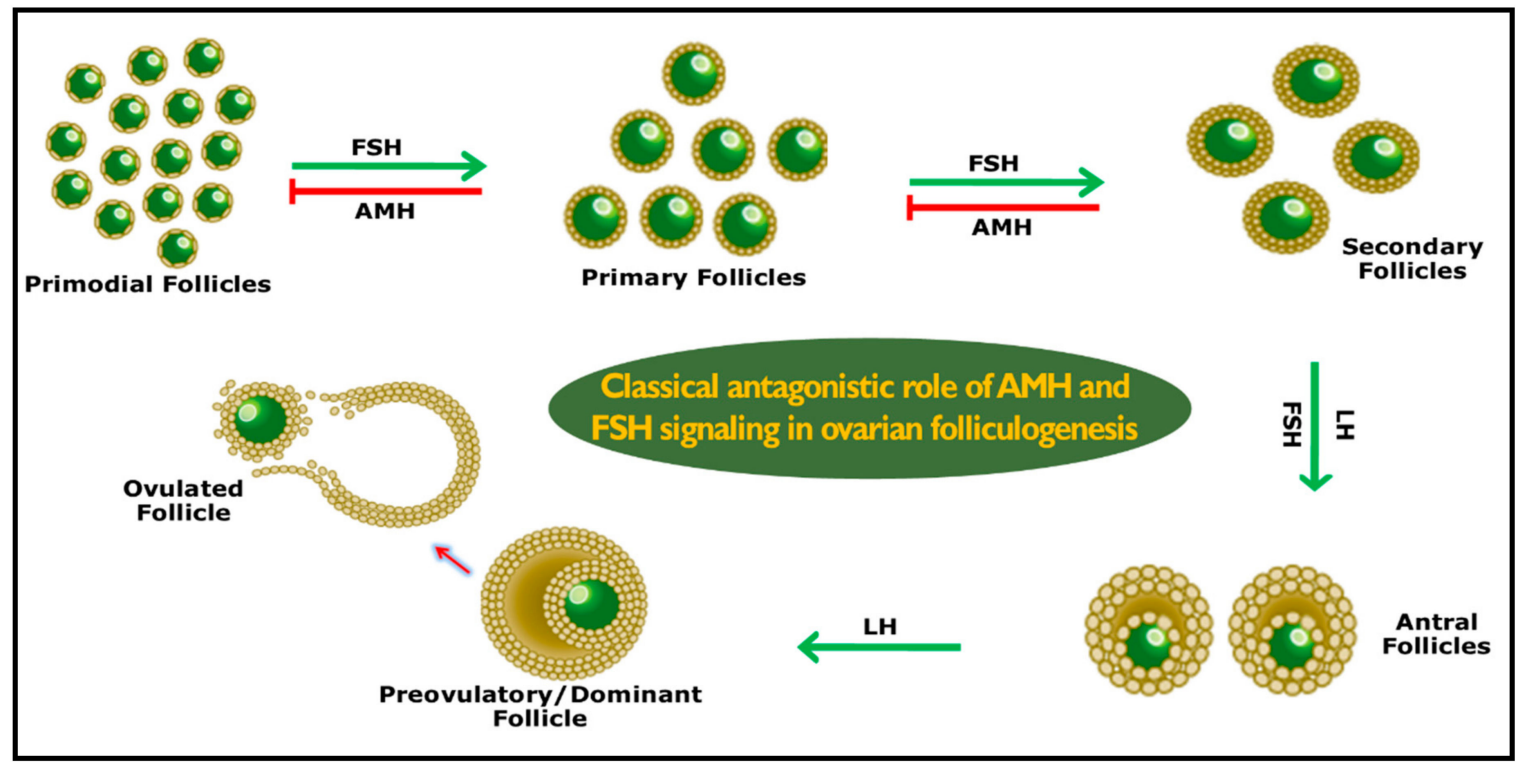

Figure 2. Schematic role of AMH which avoids the premature exhaustion of ovarian follicular reserves and selection of a dominant follicular wave. AMH works inversely to follicle-stimulating hormone (FSH) in accomplishing the aforementioned tasks. $\mathrm{LH}=$ luteinizing hormone.

\section{How Antral Follicle Count Became a Fertility Biomarker}

In the bovine estrus cycle, the growth of follicles occurs under the influence of FSH at an interval of 7-10 days [43]. The growing follicles ( $\geq 3 \mathrm{~mm}$ in diameter) were monitored by ovarian ultrasonography which revealed that the per wave antral follicle count (AFC) was highly variable (ranging from 8-54 follicles) but highly repeatable ( $1=$ perfect, 0.95$)$ during the same and the subsequent estrus cycle within each animal [44]. This study opened a new portal for confirmatory research. Ireland confirmed these findings with data from a large number of animals $(n=69)$ by monitoring 188 follicle waves [45]. In young adult beef cattle, the size of the ovary was positively associated $(r=0.89, p<0.001)$ with low vs. high AFC [46]. The basal FSH concentrations were negatively correlated with the number of follicles in dairy [47] and beef [45] heifers, and non-lactating dairy [48] and lactating beef cows [49]. The concentration of progesterone and thickening of the endometrium remains constant with both low and high AFC $(p<0.01)$ [50], while they affect the embryo mortality in cattle [51] and cause infertility in women [52]. The ovarian androgen production has no effect on low vs. high AFC in cattle [53]. In conclusion, cattle can be a phenotypically reliable animal for AFC because repeatability was not affected by age, breed, season, stage of lactation, level of hormone, nor time span of the AFC measurement $[44-47,50,54,55]$.

\section{AMH Repeatability and Relationship with AFC}

Emerging knowledge depicts that AMH level slightly varies during the estrus cycle of cattle. The measurement of the AMH level in young adult beef heifers at a single time point was found to be highly positively associated $(r=0.97)$ with the average of the AMH level determined from measurements at multiple time points at different days of multiple estrus cycles [56,57]. The AMH level remained static during the estrus cycle of dairy cows $[56,58,59]$ on different days of two estrus cycles [58], and also during the natural and synchronized estrus cycles within the same individual [60]. The average circulating level of AMH for every single cow was positively correlated $(r=0.65 ; p<0.01)$ with a superstimulated response (number of corpus luteum at the time of flushing) and total collected embryos $(r=0.50 ; p<0.01$; [59]. A positive correlation was observed between the plasma level of AMH and the numbers of ova/embryos, fertilized embryos, and transferable embryos in the Japanese black cow, which suggested that these AMH concentrations are useful for predicting early-stage markers 
for selecting Japanese black donor cows [61,62]. In mares, AMH showed a positive association with AFC within and between estrous cycles, i.e., middle-aged (9-18 years) and old mares (19-27 years) [63]. In Barki sheep, circulating AMH level was positively correlated with antral follicles $(r=0.88)$ and progesterone $\left(\mathrm{P}_{4 ;} r=0.41\right)$ [64]. The above findings indicate that $\mathrm{AMH}$ concentration could be a reliable biomarker based on a single random blood sampling at any day of a cycle in adult cattle mare and sheep.

AMH was highly positively correlated $(r=0.90)$ with the disparity in AFC and the histologically determined total number of morphologically healthy follicles (primordial, transitory, primary, secondary, and antral) and oocytes in the ovaries of young adult cattle [46]. The overall mean AMH amount during ovulatory follicular waves per animal had a highly significant correlation $(r=0.92)$ with an average peak AFC during two or three waves of an estrous cycle [46]. AMH repeatability was high between post-weaning and pre-service evaluations, which indicated that post-weaning maximum AFC and AMH concentrations may be applied to select Bradford heifers that start puberty at an early age [65]. A significant positive correlation was also assessed between AMH and the number of follicles in dairy Holstein, European, and Zebu cattle $[58,66,67]$. In mares, the repeatability of AFC and plasma $\mathrm{AMH}$ level was high because $\mathrm{AMH}$ was consistent within and between estrus cycles [63]. In sheep, AMH repeatability was low within-animal because it reached its peak concentration at different times among different animals [68]. In individuals with either a low or high AFC, this value did not show any significant association with AMH [69]. These facts highlight the importance of the relationship and reliability of both $\mathrm{AMH}$ and AFC as predictive reproductive biomarkers for the size of the reserve ovarian pool in age-matched cattle and mares, but it appears limited in sheep, and so more reports are required based on data derived at a larger scale.

\section{Fertility and Dynamics of AMH in Different Age Groups}

An experiment on Maine-Anjou beef heifers illustrates the variable level of AMH. In calves from one to three months of age, the level of AMH was increased until six months of age, and then slowly decreased from seven to 12 months. The age of first ovulation was one year for this breed [70]. Similar dynamics were found in female Holstein calves, in which the level of AMH was increased until two months of age, started to decline in the fifth month, and then stabilized when the ovulation age reached eight to nine months [70]. The AMH concentration in mares increases at an early age and reaches its peak level at around 16-18 years, and the level of AMH then declines with increasing age [71,72]. In sheep (Rasa Aragonesa; bred for wool and meat), the AMH level was not associated with lambs between prepubescence and adulthood. In prepubescent lambs, the AMH level increases from 3-4.5 months of age, while it decreases in the sixth month [68]. In another study of sheep (Sarda; bred for dairy purposes), AMH concentration tended to increase until two to five weeks of age and decline at six weeks of age [69]. These studies indicate that the AMH level was high during early life as compared to a young age in all species, but there is variation due to the age of puberty onset in different domestic species [73].

$\mathrm{AMH}$ has also been recently proposed as a potential biomarker for precocious puberty and weaning [65,74]. It is well known that heifers with precocious puberty ( $\leq 10$ months) can be bred at a lower cost than breeds with later puberty [75]. Moreover, precocious puberty allows the heifer to have more estrous cycles before breeding age, increased first-service conception rate [76], earlier pregnancy [77], and enhanced lifetime productivity [78]. Ali et al. sampled Japanese black female calves from their first week after birth until their sixth week of early puberty, and observed characteristic AMH level trends, concluding that higher levels of AMH during this period could decide the early onset of puberty and characteristic post-puberty AMH levels [74]. Later on, another study also indicated that post-weaning AMH levels may be useful for selecting Bradford heifers with precocious puberty [65]. However, these types of studies need to be evaluated at large-herd and multibreed levels to confirm the predictive ability of AMH as a biomarker for precocious puberty. Jimenez-Krassel et al. conducted a study on young adult Holstein heifers (age 11-15 months, $\mathrm{n}=281$ ). Heifers were divided into four 
quartiles based on their circulating mean $\mathrm{AMH}$ concentrations $(\mathrm{Q} 1=19 \mathrm{pg} / \mathrm{mL}, \mathrm{Q} 2=41.8 \mathrm{pg} / \mathrm{mL}$, $\mathrm{Q} 3=68.9 \mathrm{pg} / \mathrm{mL}$, and $\mathrm{Q} 4=153.2 \mathrm{pg} / \mathrm{mL}$ ); moreover, several parameters of reproductive performance before and after calving were analyzed in every individual before the start of third lactation. Conception and pregnancy rates after the first artificial insemination (heifers averaged $44.5 \% ; n=240$ animals) did not differ among quartiles. A lack of difference in results has opened a new discussion due to unexpected results with different levels of AMH [79]. If we compare low vs. high AFC heifers, low AFC heifers show diminished ovarian function, oocyte quality, and endometrial development $[50,54,80]$. Another study reported that high AMH dairy cows had higher pregnancy rates and a lower incidence of pregnancy loss between 30 to 65 days of gestation [81]. There are no significant relationships between AMH and AFC at a young age (three to eight years) in mares [63]. From these studies, we conclude that heifers showed suboptimal findings of AMH after the birth of a calf, and further research into heifers and young mares are thus needed to establish AMH as a predictive marker of fertility.

Productive herd life (time in the herd after calving) was positively associated with AMH in heifers. In the division of the above-discussed study, further analysis revealed that Q1 cows (low AMH group) had a short lactation period (180 days) as compared to Q2 and Q3 cows. The percentage of cows in Q1, Q2, Q3, and Q4 were respectively $24 \%, 37 \%, 43 \%$, and $32 \%$ after culling in the herd. This result indicates that the probability of culling was high in Q1 group as compared to the other three groups $(\mathrm{Q} 2, \mathrm{Q} 3, \mathrm{Q} 4)$. These findings lead to the conclusion that a single test of circulating AMH concentration in young heifers can predict herd longevity [79].

It has been shown that the quantity of AMH varies slightly during the same days of two estrus cycles in the same cattle $[58,59]$. In dairy cows, during the natural and synchronized estrus cycle of the same individual, the AMH concentration remains the same [60], while in goats, the level of $\mathrm{AMH}$ and FSH increased after synchronization as compared to a natural estrus cycle [82]. In beef heifers, the value of a single AMH measurement was strongly correlated with the average of multiple measurements of AMH during different days of multiple estrus cycles [57]. Altogether, these reports summarized the stable nature of AMH during the estrus cycle and its repeatability among multiple estrus cycles in bovines and mares. These studies further highlight the potential utility of AMH as a reproductive marker based on a single blood sample from adult cattle and mares.

\section{AMH and Assisted Reproductive Technologies}

In assisted reproductive technologies (ART), both AMH and AFC were used as markers for superstimulation, but the response of superovulation was negatively correlated with the number of follicles and ova in cattle ovaries [49,83-85]. Over time, scientific reports in the favor of AMH as a marker for superovulatory response has increased. AMH had a positive association with follicles before and after treatment, and with the corpus luteum (CL) of the ovary [58]. In dry dairy cows, AMH showed a high correlation with the number of graphian follicles and number of embryos collected using the multiple ovulation and embryo transfer (MOET) protocol [86], and a similar relationship was found in Japanese black beef cattle [62,87]. A superstimulation response was also correlated with circulating AMH levels of lactating Holstein cows [59]. A positive association was established between ovum pick-up (OPU) and AMH in Bos indicus (Zebu; [88], beef Korean Hanwoo; [89] and Holstein [90] cows) for MOET. Furthermore, AMH measurements were also used as a predictive marker for the superovulatory response in goats [91], sheep [68], mares [33], and buffalo [31]. In donor ewes, AMH can be used as a reliable marker for superovulation and the in vivo embryo production response [92]. This evidence confirms that the concentration of AMH could be used as predictive marker for the ovulation response in the field of ART, especially in superovulation.

\section{Heritability of AMH}

In dairy and beef cattle, the heritability of female reproductive traits is low [93]. In spite of that, the advancement of genetic improvement by the identification of biomarkers has a positive association with moderate to highly heritable traits and fertility in dairy cattle. Two reports were 
recently established to estimate AMH heritability. Approximately, 2905 Holstein heifers (11-15 months of age) were used for circulating AMH measurements and then genotyped for SNP (single-nucleotide polymorphism) markers, and their pedigree data from the last four generations were collected. The genomic heritability was $0.36 \pm 0.03$ for AMH [94], and another research team also reported similar heritability $(0.46 \pm 0.31)$ by using data from 198 Canadian Holstein cows [95]. The heritability of $\mathrm{AMH}$ on pedigree-based information was estimated as $0.43 \pm 0.07$ [94]. These estimated heritability traits (genomic and pedigree) were higher than any previously published reports for traits related to reproduction in cattle [93]. The heritability of AFC in dairy heifers and cows was $0.25 \pm 0.13$ and $0.31 \pm 0.14$, respectively. As per previous reports, AFC was revealed to be a moderately heritable genetic trait [96].

By genome-wide association analysis, a relevant overlap was found between the genes influencing $\mathrm{AMH}$ concentrations and those which affect the superovulatory traits in cattle [94]. For example, prostaglandin-endoperoxide synthase 1 (PTSGS1) was associated with AMH [94], a gene that had been found positively correlated with the number of ova/collectable and viable embryos in cattle [97]. Given that numerous findings $[55,94,95]$ have revealed that fertility might be improved by genetic selection of the size of the ovarian pool (as assessed by AFC and AMH) in cattle, the economically relevant production traits that correlate with potential positive genetic traits need to be determined as AMH was not associated with the level of milk production [79], while AFC was negatively correlated with genetic merit for milk fat concentration [96].

\section{Factors Affecting AMH}

\subsection{Nutrition}

The ovarian follicle pool is ascertained during fetal life [98]. Consequently, pregnant dam management in cattle has a pivotal impact on the environment of conceptus development, thus impacting on the establishment of the ovarian pool. Hypothetically, in the first trimester of a pregnant dam, restriction of dietary nutrition up to $60 \%$ of maternal requirement has a lifelong impact on the establishment of ovarian reserves in offspring (beef cattle) [99]. The restriction of nutrition has a significant impact on the ovarian reserves of heifers born to experimental mothers, reduced plasma AMH levels (four months to 1.8 years), lower AFC (seven weeks to 1.6 years), and increased FSH concentration $[44,99]$. Another study found that a high level of protein fed to cattle during gestation impaired the AFC in offspring [100], predicting that an imbalanced diet and other fetal life events could have a long-lasting impact on the later fertile life of cattle.

\subsection{Hormones}

Endocrine-disrupting chemicals (natural and artificial) have a potential impact on the physiology, offspring, and reproduction of animals [101]. In sheep, excessive testosterone exposure during pregnancy (especially during day 30-90) reduces the AMH expression in granulosa cells of preantral follicles. Moreover, AMH expression levels increase in young adult antral follicles as compared to controls, while no effect was detected in prepubescent lambs [30]. In Chinese goats (Chongming White), superovulation treatment with CIDR-FSH-PGF2a-LH increases the ovulation and level of FSH and AMH in serum [82]. The above reports revealed that testosterone and inhibin immunization before superovulation brings about changes in AMH expression and concentration, suggesting that these hormones have a role in the regulation of ovarian reserves.

\subsection{Disease}

Ovarian diseases can lead to altered ovarian function, contributing to the follicular persistence and endocrine/paracrine changes found in domestic animals. AMH emerged as a potential biomarker for several ovarian tumors in cows [56,102,103], mares [104,105], dogs [106], and cats [107]. Moreover, $\mathrm{AMH}$ has been reported as a potential tool for monitoring bovine granulosa-theca cell tumor (GTCT) 
spontaneous recovery [108]. In women, polycystic ovarian syndrome (PCOS) showed a three-fold higher AMH level as compared to normal, indicating the higher load of growing follicles [109], whereas in cattle, the expression and concentration of $\mathrm{AMH}$ are clearly altered in the course of follicular persistence and in developed cystic ovarian disease (COD) [110]. Furthermore, elevated AMH has been reported in bitches with luteinized follicular cysts [106]. As per the above reports, AMH can be used as potential diagnostic tool for ovarian tumors in many domestic animals, but the predictive ability for cystic diseases is still controversial, and so further studies are required.

Naturally, gestation and lactation traits are interlinked by hypothesis. Cows were selected as having a chronic mammary gland infection (increased somatic cell count (SCC)) [111], and daughter heifers have low circulating AMH levels [57]. In conclusion, severe/persistent mammary gland infections have an impact on the offspring ovarian reserves during gestation.

\subsection{Granulosa Cells}

In superstimulation treatment, cattle with low AFC show a poor response [45]. To test this phenomenon, an in vitro model was designed to check the response of the granulosa cells among low and high AFC individuals under different concentrations of FSH. The expression and quantity of AMH mRNA were measured. Overall results indicated that the abundance and expression of AMH were relatively lower in the low AFC group in comparison with the high AFC group. This report revealed that the low AFC granulosa cells responded less to FSH, while the FSH concentration in low AFC cattle was chronically high $[44,45,48,50]$. The debate over whether cattle with lower ovarian reserves show less of a refractory response to FSH during the reproductive cycle and superovulatory treatment is still unclear or only partially explained [45,49,83-85].

\section{Conclusions}

Recently, AMH has become a hot topic for researchers due to its ability to make predictions regarding the ovarian reserve pool. Due to its static nature, the collection of a single dose of blood has become more popular in the field of ART. In contrast to AFC, the strong genomic and pedigree-based heritability of AMH strengthens the case for its use as a reproductive biomarker of fertility. The peripheral AMH level has become representative of the ovarian reserve pool and is currently a promising marker for fertility and a diagnostic marker for ovarian disorders in domestic animals. The relationship with reproductive performance parameters-i.e., breed, age, longevity, fertility, and ovarian reserves (for heifers) - needs further confirmation within large herds. The impact of management factors (disease and nutrition), hormones, and lower response of AFC to cattle and goat granulosa cells opens a new pathway for future research. In many domestic farm animal species, the association of AMH to fertility superovulation and disease remains unexplored.

Author Contributions: S.U., S.J.Z. and H.Z. conceived the idea and outlined the sketch. S.U. and S.J.Z. wrote the initial manuscript. A.S. assisted in figures and literature. B.W.S. modified the manuscript. S.J.Z. and Y.P. substantially revised the manuscript. S.U. and S.J.Z. contributed equally to this work. All authors read the manuscript and consented for publication.

Funding: This work was supported by the National Key R\&D Program of China (2017YFD0501903).

Acknowledgments: This review is dedicated to renowned animal scientists like Nathalie Josso, James J. Ireland, Francesca Mossa, Claes AN and Ball BA and many others. Their extensive work helped to increase our understanding of $\mathrm{AMH}$ and its predictive ability in domestic animal species. We are very thankful to Muhammad Khalid (Farm Animal Health and Production Group, The Royal Veterinary College, London, UK) and Rezwan Tariq (Chinese Academy of Agricultural Sciences) for their extensive English editing.

Conflicts of Interest: The authors declare that they have no competing interests. 


\section{References}

1. Jost, A. Problems of fetal endocrinology: The gonadal and hypophyseal hormones. Recent Prog. Horm. Res. 1953, 8, 379-413.

2. Picon, R. Action du testicule foetal sur le développement in vitro des canaux de Müller chez le rat. Arch. Anat. Microsc. Morphol. Exp. 1969, 58,1-19. [PubMed]

3. Picard, J.-Y.; Josso, N. Purification of testicular anti-Müllerian hormone allowing direct visualization of the pure glycoprotein and determination of yield and purification factor. Mol. Cell. Endocrinol. 1984, 34, $23-29$. [CrossRef]

4. Vigier, B.; Picard, J.-Y.; Tran, D.; Legeai, L.; Josso, N. Production of anti-Müllerian hormone: Another homology between Sertoli and granulosa cells. Endocrinology 1984, 114, 1315-1320. [CrossRef]

5. Takahashi, M.; Hayashi, M.; Manganaro, T.F.; Donahoe, P.K. The ontogeny of mullerian inhibiting substance in granulosa-cells of the bovine ovarian follicle. Biol. Reprod. 1986, 35, 447-453. [CrossRef]

6. Bézard, J.; Vigier, B.; Tran, D.; Mauleon, P.; Josso, N. Immunocytochemical study of anti-Müllerian hormone in sheep ovarian follicles during fetal and post-natal development. J. Reprod. Fertil. 1987, 80, 509-516. [CrossRef]

7. Josso, N. Remembrance of Dr. Alfred Jost. Endocrinology 1991, 129, 2274-2276.

8. Teixeira, J.; Maheswaran, S.; Donahoe, P.K. Mullerian inhibiting substance: An instructive developmental hormone with diagnostic and possible therapeutic applications. Endocr. Rev. 2001, 22, 657-674. [CrossRef]

9. Cate, R.L.; Mattaliano, R.J.; Hession, C.; Tizard, R.; Farber, N.M.; Cheung, A.; Ninfa, E.G.; Frey, A.Z.; Gash, D.J.; Chow, E.P. Isolation of the bovine and human genes for Müllerian inhibiting substance and expression of the human gene in animal cells. Cell 1986, 45, 685-698. [CrossRef]

10. Josso, N.; Di Clemente, N. Transduction pathway of anti-Müllerian hormone, a sex-specific member of the TGF- $\beta$ family. Trends Endocrinol. Metab. 2003, 14, 91-97. [CrossRef]

11. Claes, A.; Ball, B.A.; Almeida, J.; Corbin, C.J.; Conley, A.J. Serum anti-Müllerian hormone concentrations in stallions: Developmental changes, seasonal variation, and differences between intact stallions, cryptorchid stallions, and geldings. Theriogenology 2013, 79, 1229-1235. [CrossRef] [PubMed]

12. Gao, Q.; Womack, J.E. A genetic map of bovine chromosome 7 with an interspecific hybrid backcross panel. Mamm. Genome 1997, 8, 258-261. [CrossRef] [PubMed]

13. NCBI. Available online: https://www.ncbi.nlm.nih.gov/pubmed (accessed on 3 April 2019).

14. Monniaux, D.; Barbey, S.; Rico, C.; Fabre, S.; Gallard, Y.; Larroque, H. Anti-Müllerian hormone: A predictive marker of embryo production in cattle? Reprod. Fertil. Dev. 2010, 22, 1083-1091. [CrossRef] [PubMed]

15. Massagué, J. TGF- $\beta$ signal transduction. Annu. Rev. Biochem. 1998, 67, 753-791.

16. Massagué, J.; Wotton, D. Transcriptional control by the TGF- $\beta /$ Smad signaling system. EMBO J. 2000, 19, 1745-1754. [CrossRef]

17. Visser, J.A. AMH signaling: From receptor to target gene. Mol. Cell. Endocrinol. 2003, 211, 65-73. [CrossRef]

18. Moustakas, A.; Heldin, C.H. Non-Smad TGF-beta signals. J. Cell Sci. 2005, 118, 3573-3584. [CrossRef]

19. Yi, J.Y.; Shin, I.; Arteaga, C.L. Type I transforming growth factor $\beta$ receptor binds to and activates phosphatidylinositol 3-kinase. J. Biol. Chem. 2005, 280, 10870-10876. [CrossRef]

20. Baarends, W.M.; Van Helmond, M.J.; Post, M.; van Der Schoot, P.J.; Hoogerbrugge, J.W.; de Winter, J.P.; Uilenbroek, J.T.; Karels, B.; Wilming, L.G.; Meijers, J.H. A novel member of the transmembrane serine/threonine kinase receptor family is specifically expressed in the gonads and in mesenchymal cells adjacent to the mullerian duct. Development 1994, 120, 189-197.

21. Miyazono, K.; Kamiya, Y.; Morikawa, M. Bone morphogenetic protein receptors and signal transduction. J. Biochem. 2010, 147, 35-51. [CrossRef]

22. Erickson, G.F.; Shimasaki, S. The spatiotemporal expression pattern of the bone morphogenetic protein family in rat ovary cell types during the estrous cycle. Reprod. Biol. Endocrinol. 2003, 1, 9. [CrossRef] [PubMed]

23. Shimasaki, S.; Zachow, R.J.; Li, D.; Kim, H.; Iemura, S.; Ueno, N.; Sampath, K.; Chang, R.J.; Erickson, G.F. A functional bone morphogenetic protein system in the ovary. Proc. Natl. Acad. Sci. USA 1999, 96, 7282-7287. [CrossRef] [PubMed]

24. Shimasaki, S.; Moore, R.K.; Otsuka, F.; Erickson, G.F. The bone morphogenetic protein system in mammalian reproduction. Endocr. Rev. 2004, 25, 72-101. [CrossRef] [PubMed] 
25. Zhao, Z.; Guo, F.; Sun, X.; He, Q.; Dai, Z.; Chen, X.; Zhao, Y.; Wang, J. BMP15 regulates AMH expression via the p38 MAPK pathway in granulosa cells from goat. Theriogenology 2018, 118, 72-79. [CrossRef] [PubMed]

26. McGee, E.A.; Hsueh, A.J.W. Initial and cyclic recruitment of ovarian follicles. Endocr. Rev. 2000, 21, $200-214$. [CrossRef] [PubMed]

27. UENO, S.; Kuroda, T.; Maclaughlin, D.T.; Ragin, R.C.; Manganaro, T.F.; Donahoe, P.K. Mullerian inhibiting substance in the adult rat ovary during various stages of the estrous cycle. Endocrinology 1989, 125, 1060-1066. [CrossRef]

28. Weenen, C.; Laven, J.S.E.; von Bergh, A.R.M.; Cranfield, M.; Groome, N.P.; Visser, J.A.; Kramer, P.; Fauser, B.C.J.M.; Themmen, A.P.N. Anti-Müllerian hormone expression pattern in the human ovary: Potential implications for initial and cyclic follicle recruitment. MHR Basic Sci. Reprod. Med. 2004, 10, 77-83. [CrossRef]

29. Monniaux, D.; Clemente, N.D.; Touzé, J.-L.; Belville, C.; Rico, C.; Bontoux, M.; Picard, J.-Y.; Fabre, S. Intrafollicular steroids and anti-Müllerian hormone during normal and cystic ovarian follicular development in the cow. Biol. Reprod. 2008, 79, 387-396. [CrossRef]

30. Veiga-Lopez, A.; Ye, W.; Padmanabhan, V. Developmental programming: Prenatal testosterone excess disrupts anti-Müllerian hormone expression in preantral and antral follicles. Fertil. Steril. 2012, 97, 748-756. [CrossRef]

31. Liang, A.; Salzano, A.; D’Esposito, M.; Comin, A.; Montillo, M.; Yang, L.; Campanile, G.; Gasparrini, B. Anti-Mullerian hormone (AMH) concentration in follicular fluid and mRNA expression of AMH receptor type II and LH receptor in granulosa cells as predictive markers of good buffalo (Bubalus bubalis) donors. Theriogenology 2016, 86, 963-970. [CrossRef]

32. Rocha, R.M.P.; Lima, L.F.; Carvalho, A.A.; Chaves, R.N.; Bernuci, M.P.; Rosa-e-Silva, A.C.J.S.; Rodrigues, A.P.R.; Campello, C.C.; Figueiredo, J.R. Immunolocalization of the Anti-Müllerian Hormone (AMH) in caprine follicles and the effects of AMH on in vitro culture of caprine pre-antral follicles enclosed in ovarian tissue. Reprod. Domest. Anim. 2016, 51, 212-219. [CrossRef] [PubMed]

33. Claes, A.; Ball, B.A.; Troedsson, M.H.T.; Curry, T.E.; Squires, E.L.; Scoggin, K.E. Molecular changes in the equine follicle in relation to variations in antral follicle count and anti-Müllerian hormone concentrations. Equine Vet. J. 2016, 48, 741-748. [CrossRef] [PubMed]

34. Almeida, F.R.C.L.; Costermans, N.G.J.; Soede, N.M.; Bunschoten, A.; Keijer, J.; Kemp, B.; Teerds, K.J. Presence of anti-Müllerian hormone (AMH) during follicular development in the porcine ovary. PLoS ONE 2018, 13, e0197894. [CrossRef] [PubMed]

35. Durlinger, A.L.L.; Kramer, P.; Karels, B.; de Jong, F.H.; Uilenbroek, J.T.J.; Grootegoed, J.A.; Themmen, A.P.N. Control of primordial follicle recruitment by anti-Mullerian hormone in the mouse ovary. Endocrinology 1999, 140, 5789-5796. [CrossRef] [PubMed]

36. Durlinger, A.L.L.; Gruijters, M.J.G.; Kramer, P.; Karels, B.; Kumar, T.R.; Matzuk, M.M.; Rose, U.M.; de Jong, F.H.; Uilenbroek, J.T.J.; Grootegoed, J.A. Anti-Mullerian hormone attenuates the effects of FSH on follicle development in the mouse ovary. Endocrinology 2001, 142, 4891-4899. [CrossRef]

37. Pellatt, L.; Rice, S.; Dilaver, N.; Heshri, A.; Galea, R.; Brincat, M.; Brown, K.; Simpson, E.R.; Mason, H.D. Anti-Müllerian hormone reduces follicle sensitivity to follicle-stimulating hormone in human granulosa cells. Fertil. Steril. 2011, 96, 1246-1251. [CrossRef]

38. Gordon, I. The bovine oestrous cycle and associated events. In Laboratory Production of Cattle Embryos; CABI: Wallingford, UK, 2009.

39. Di Clemente, N.; Goxe, B.; Remy, J.J.; Cate, R.L.; Josso, N.; Vigier, B.; Salesse, R. Inhibitory effect of AMH upon aromatase activity and LH receptors of granulosa cells of rat and porcine immature ovaries. Endocrine 1994, 2, 553-558.

40. Ayalon, D.; Tsafriri, A.; Lindner, H.; Cordova, T.; Harell, A. Serum gonadotropin levels in pro-oestrous rats in relation to the resumption of meiosis by the oocytes. J. Reprod. Fertil. 1972, 31, 51-58. [CrossRef]

41. Takahashi, M.; Koide, S.; Donahoe, P. Müllerian inhibiting substance as oocyte meiosis inhibitor. Mol. Cell. Endocrinol. 1986, 47, 225-234. [CrossRef]

42. Dewailly, D.; Andersen, C.Y.; Balen, A.; Broekmans, F.; Dilaver, N.; Fanchin, R.; Griesinger, G.; Kelsey, T.W.; La Marca, A.; Lambalk, C. The physiology and clinical utility of anti-Müllerian hormone in women. Hum. Reprod. Update 2014, 20, 370-385. [CrossRef] 
43. Adams, G.P.; Matteri, R.L.; Kastelic, J.P.; Ko, J.C.H.; Ginther, O.J. Association between surges of follicle-stimulating hormone and the emergence of follicular waves in heifers. Reproduction 1992, 94, 177-188. [CrossRef] [PubMed]

44. Burns, D.S.; Jimenez-Krassel, F.; Ireland, J.L.H.; Knight, P.G.; Ireland, J.J. Numbers of antral follicles during follicular waves in cattle: Evidence for high variation among animals, very high repeatability in individuals, and an inverse association with serum follicle-stimulating hormone concentrations. Biol. Reprod. 2005, 73, 54-62. [CrossRef] [PubMed]

45. Ireland, J.J.; Ward, F.; Jimenez-Krassel, F.; Ireland, J.L.H.; Smith, G.W.; Lonergan, P.; Evans, A.C.O. Follicle numbers are highly repeatable within individual animals but are inversely correlated with FSH concentrations and the proportion of good-quality embryos after ovarian stimulation in cattle. Hum. Reprod. 2007, 22, 1687-1695. [CrossRef] [PubMed]

46. Ireland, J.L.H.; Scheetz, D.; Jimenez-Krassel, F.; Themmen, A.P.N.; Ward, F.; Lonergan, P.; Smith, G.W.; Perez, G.I.; Evans, A.C.O.; Ireland, J.J. Antral follicle count reliably predicts number of morphologically healthy oocytes and follicles in ovaries of young adult cattle. Biol. Reprod. 2008, 79, 1219-1225. [CrossRef] [PubMed]

47. Haughian, J.M.; Ginther, O.J.; Kot, K.; Wiltbank, M.C. Relationships between FSH patterns and follicular dynamics and the temporal associations among hormones in natural and GnRH-induced gonadotropin surges in heifers. Reproduction 2004, 127, 23-33. [CrossRef]

48. Mossa, F.; Jimenez-Krassel, F.; Folger, J.K.; Ireland, J.L.H.; Smith, G.W.; Lonergan, P.; Evans, A.C.O.; Ireland, J.J. Evidence that high variation in antral follicle count during follicular waves is linked to alterations in ovarian androgen production in cattle. Reproduction 2010, 140, 713. [CrossRef]

49. Singh, J.; Domínguez, M.; Jaiswal, R.; Adams, G.P. A simple ultrasound test to predict the superstimulatory response in cattle. Theriogenology 2004, 62, 227-243. [CrossRef]

50. Jimenez-Krassel, F.; Folger, J.K.; Ireland, J.L.H.; Smith, G.W.; Hou, X.; Davis, J.S.; Lonergan, P.; Evans, A.C.O.; Ireland, J.J. Evidence that high variation in ovarian reserves of healthy young adults has a negative impact on the corpus luteum and endometrium during estrous cycles in cattle. Biol. Reprod. 2009, 80, 1272-1281. [CrossRef]

51. Diskin, M.G.; Morris, D.G. Embryonic and early foetal losses in cattle and other ruminants. Reprod. Domest. Anim. 2008, 43, 260-267. [CrossRef]

52. Basir, G.S.; So, W.W.K.; Ng, E.H.Y.; Ho, P.C. Evaluation of cycle-to-cycle variation of endometrial responsiveness using transvaginal sonography in women undergoing assisted reproduction. Ultrasound Obstet. Gynecol. 2002, 19, 484-489. [CrossRef]

53. Scheetz, D.; Folger, J.K.; Smith, G.W.; Ireland, J.J. Granulosa cells are refractory to FSH action in individuals with a low antral follicle count. Reprod. Fertil. Dev. 2012, 24, 327-336. [CrossRef] [PubMed]

54. Ireland, J.J.; Zielak-Steciwko, A.E.; Jimenez-Krassel, F.; Folger, J.; Bettegowda, A.; Scheetz, D.; Walsh, S.; Mossa, F.; Knight, P.G.; Smith, G.W. Variation in the ovarian reserve is linked to alterations in intrafollicular estradiol production and ovarian biomarkers of follicular differentiation and oocyte quality in cattle. Biol. Reprod. 2009, 80, 954-964. [CrossRef] [PubMed]

55. Mossa, F.; Walsh, S.W.; Butler, S.T.; Berry, D.P.; Carter, F.; Lonergan, P.; Smith, G.W.; Ireland, J.J.; Evans, A.C.O. Low numbers of ovarian follicles $\geq 3 \mathrm{~mm}$ in diameter are associated with low fertility in dairy cows. J. Dairy Sci. 2012, 95, 2355-2361. [CrossRef] [PubMed]

56. El-Sheikh Ali, H.; Kitahara, G.; Nibe, K.; Yamaguchi, R.; Horii, Y.; Zaabel, S.; Osawa, T. Plasma anti-Müllerian hormone as a biomarker for bovine granulosa-theca cell tumors: Comparison with immunoreactive inhibin and ovarian steroid concentrations. Theriogenology 2013, 80, 940-949. [CrossRef] [PubMed]

57. Ireland, J.J.; Smith, G.W.; Scheetz, D.; Jimenez-Krassel, F.; Folger, J.K.; Ireland, J.L.H.; Mossa, F.; Lonergan, P.; Evans, A.C.O. Does size matter in females? An overview of the impact of the high variation in the ovarian reserve on ovarian function and fertility, utility of anti-Müllerian hormone as a diagnostic marker for fertility and causes of variation in the ovarian reserve in. Reprod. Fertil. Dev. 2010, 23, 1-14. [CrossRef] [PubMed]

58. Rico, C.; Fabre, S.; Médigue, C.; Clemente, N.D.; Clément, F.; Bontoux, M.; Touzé, J.-L.; Dupont, M.; Briant, E.; Rémy, B. Anti-Müllerian hormone is an endocrine marker of ovarian gonadotropin-responsive follicles and can help to predict superovulatory responses in the cow. Biol. Reprod. 2009, 80, 50-59. [CrossRef] [PubMed] 
59. Souza, A.H.; Carvalho, P.D.; Rozner, A.E.; Vieira, L.M.; Hackbart, K.S.; Bender, R.W.; Dresch, A.R.; Verstegen, J.P.; Shaver, R.D.; Wiltbank, M.C. Relationship between circulating anti-Müllerian hormone (AMH) and superovulatory response of high-producing dairy cows. J. Dairy Sci. 2015, 98, 169-178. [CrossRef]

60. Pfeiffer, K.E.; Jury, L.J.; Larson, J.E. Determination of anti-Müllerian hormone at estrus during a synchronized and a natural bovine estrous cycle. Domest. Anim. Endocrinol. 2014, 46, 58-64. [CrossRef]

61. Nabenishi, H.; Kitahara, G.; Takagi, S.; Yamazaki, A.; Osawa, T. Relationship between plasma anti-Müllerian hormone concentrations during the rearing period and subsequent embryo productivity in Japanese black cattle. Domest. Anim. Endocrinol. 2017, 60, 19-24. [CrossRef]

62. Hirayama, H.; Naito, A.; Fujii, T.; Sugimoto, M.; Takedomi, T.; Moriyasu, S.; Sakai, H.; Kageyama, S. Effects of genetic background on responses to superovulation in Japanese Black cattle. J. Vet. Med. Sci. 2019, 81, 373-378. [CrossRef]

63. Claes, A.; Ball, B.A.; Scoggin, K.E.; Esteller-Vico, A.; Kalmar, J.J.; Conley, A.J.; Squires, E.L.; Troedsson, M.H.T. The interrelationship between anti-Müllerian hormone, ovarian follicular populations and age in mares. Equine Vet. J. 2015, 47, 537-541. [CrossRef] [PubMed]

64. Waheeb, R.S. Changes in serum levels of anti-mullerian hormone and ovarian steroids in Barki sheep during follicular and early luteal phase of estrous cycle. Pak. Vet. J. 2017, 37, 421-426.

65. Santa Cruz, R.; Cushman, R.A.; Viñoles, C. Antral follicular count is a tool that may allow the selection of more precocious Bradford heifers at weaning. Theriogenology 2018, 119, 35-42. [CrossRef] [PubMed]

66. Baldrighi, J.M.; Sá Filho, M.F.D.; Batista, E.D.O.S.; Lopes, R.N.V.R.; Visintin, J.A.; Baruselli, P.S.; Assumpção, M.E.O.A. Anti-Mullerian Hormone Concentration and Antral Ovarian Follicle Population in M urrah H eifers Compared to Holstein and G yr Kept Under the Same Management. Reprod. Domest. Anim. 2014, 49, 1015-1020. [CrossRef] [PubMed]

67. Carter, A.S.; Mahboubi, K.; Costa, N.N.; Gillis, D.J.; Carter, T.F.; Neal, M.S.; Miranda, M.S.; Ohashi, O.M.; Favetta, L.A.; King, W.A. Systemic and local anti-Mullerian hormone reflects differences in the reproduction potential of Zebu and European type cattle. Anim. Reprod. Sci. 2016, 167, 51-58. [CrossRef]

68. Lahoz, B.; Alabart, J.L.; Cocero, M.J.; Monniaux, D.; Echegoyen, E.; Sánchez, P.; Folch, J. Anti-Müllerian hormone concentration in sheep and its dependence of age and independence of BMP15 genotype: An endocrine predictor to select the best donors for embryo biotechnologies. Theriogenology 2014, 81, 347-357. [CrossRef]

69. Torres-Rovira, L.; Succu, S.; Pasciu, V.; Manca, M.E.; Gonzalez-Bulnes, A.; Leoni, G.G.; Pennino, M.G.; Spezzigu, A.; Gallus, M.; Dattena, M.; et al. Postnatal pituitary and follicular activation: A revisited hypothesis in a sheep model. Reproduction 2016, 151, 215-225. [CrossRef]

70. Monniaux, D.; Drouilhet, L.; Rico, C.; Estienne, A.; Jarrier, P.; Touzé, J.-L.; Sapa, J.; Phocas, F.; Dupont, J.; Dalbiès-Tran, R. Regulation of anti-Müllerian hormone production in domestic animals. Reprod. Fertil. Dev. 2012, 25, 1-16. [CrossRef]

71. Ball, B.A.; El-Sheikh Ali, H.; Scoggin, K.E.; Riddle, W.T.; Schnobrich, M.; Bradekamp, E.; Agnew, M.; Squires, E.L.; Troedsson, M.H.T. Relationship between anti-Müllerian hormone and fertility in the mare. Theriogenology 2019, 125, 335-341. [CrossRef]

72. Uliani, R.C.; Conley, A.J.; Jo Corbin, C.; Friso, A.M.; Maciel, L.F.S.; Alvarenga, M.A. Anti-Müllerian hormone and ovarian aging in mares. J. Endocrinol. 2019, 240, 147-156. [CrossRef]

73. Evans, A.C.O.; Adams, G.P.; Rawling, N.C. Follicular and hormonal development in prepubertal heifers from 2 to 36 weeks of age. Reproduction 1994, 102, 463-470. [CrossRef] [PubMed]

74. Ali, H.E.S.; Kitahara, G.; Takahashi, T.; Mido, S.; Sadawy, M.; Kobayashi, I.; Hemmi, K.; Osawa, T. Plasma anti-Müllerian hormone profile in heifers from birth through puberty and relationship with puberty onset. Biol. Reprod. 2017, 97, 153-161.

75. Wehrman, M.E.; Kojima, F.N.; Sanchez, T.; Mariscal, D.V.; Kinder, J.E. Incidence of precocious puberty in developing beef heifers. J. Anim. Sci. 1996, 74, 2462-2467. [CrossRef] [PubMed]

76. Buskirk, D.D.; Faulkner, D.B.; Ireland, F.A. Increased postweaning gain of beef heifers enhances fertility and milk production. J. Anim. Sci. 1995, 73, 937-946. [CrossRef]

77. Bagley, C.P. Nutritional management of replacement beef heifers: A review. J. Anim. Sci. 1993, 71, 3155-3163. [CrossRef]

78. Lesmeister, J.L.; Burfening, P.J.; Blackwell, R.L. Date of first calving in beef cows and subsequent calf production. J. Anim. Sci. 1973, 36, 1-6. [CrossRef] 
79. Jimenez-Krassel, F.; Scheetz, D.M.; Neuder, L.M.; Ireland, J.L.H.; Pursley, J.R.; Smith, G.W.; Tempelman, R.J.; Ferris, T.; Roudebush, W.E.; Mossa, F. Concentration of anti-Müllerian hormone in dairy heifers is positively associated with productive herd life. J. Dairy Sci. 2015, 98, 3036-3045. [CrossRef]

80. Mossa, F.; Jimenez-Krassel, F.; Walsh, S.; Berry, D.P.; Butler, S.T.; Folger, J.; Smith, G.W.; Ireland, J.L.H.; Lonergan, P.; Ireland, J.J. Inherent capacity of the pituitary gland to produce gonadotropins is not influenced by the number of ovarian follicles $\geq 3 \mathrm{~mm}$ in diameter in cattle. Reprod. Fertil. Dev. 2010, 22, 550-557. [CrossRef]

81. Ribeiro, E.S.; Bisinotto, R.S.; Lima, F.S.; Greco, L.F.; Morrison, A.; Kumar, A.; Thatcher, W.W.; Santos, J.E.P. Plasma anti-Müllerian hormone in adult dairy cows and associations with fertility. J. Dairy Sci. 2014, 97, 6888-6900. [CrossRef]

82. Lei, G.; Wu, C.; Dai, J.; Li, Y.; Lu, Y.; Chen, X.; Zhang, S.; Zhang, D. Effects of inhibin immunization on superovulation in Chongming white goats. Acta Agric. Shanghai 2018, 34, 96-100.

83. KAWAMATA, M. Relationships between the number of small follicles prior to superovulatory treatment and superovulatory response in Holstein cows. J. Vet. Med. Sci. 1994, 56, 965-967. [CrossRef] [PubMed]

84. Cushman, R.A.; Allan, M.F.; Kuehn, L.A.; Snelling, W.M.; Cupp, A.S.; Freetly, H.C. Evaluation of antral follicle count and ovarian morphology in crossbred beef cows: Investigation of influence of stage of the estrous cycle, age, and birth weight. J. Anim. Sci. 2009, 87, 1971-1980. [CrossRef] [PubMed]

85. Taneja, M.; Bols, P.E.J.; de Velde, A.V.; Ju, J.-C.; Schreiber, D.; Tripp, M.W.; Levine, H.; Echelard, Y.; Riesen, J.; Yang, X. Developmental competence of juvenile calf oocytes in vitro and in vivo: Influence of donor animal variation and repeated gonadotropin stimulation. Biol. Reprod. 2000, 62, 206-213. [CrossRef] [PubMed]

86. Rico, C.; Drouilhet, L.; Salvetti, P.; Dalbiès-Tran, R.; Jarrier, P.; Touzé, J.-L.; Pillet, E.; Ponsart, C.; Fabre, S.; Monniaux, D. Determination of anti-Müllerian hormone concentrations in blood as a tool to select Holstein donor cows for embryo production: From the laboratory to the farm. Reprod. Fertil. Dev. 2012, 24, 932-944. [CrossRef]

87. Hirayama, H.; Kageyama, S.; Naito, A.; Fukuda, S.; Fujii, T.; Minamihashi, A. Prediction of superovulatory response in Japanese Black cattle using ultrasound, plasma anti-Müllerian hormone concentrations and polymorphism in the ionotropic glutamate receptor AMPA1/GRIA. J. Reprod. Dev. 2012, 58, 380-383. [CrossRef]

88. Guerreiro, B.M.; Batista, E.O.S.; Vieira, L.M.; Sá Filho, M.F.; Rodrigues, C.A.; Netto, A.C.; Silveira, C.R.A.; Bayeux, B.M.; Dias, E.A.R.; Monteiro, F.M. Plasma anti-mullerian hormone: An endocrine marker for in vitro embryo production from Bos taurus and Bos indicus donors. Domest. Anim. Endocrinol. 2014, 49, 96-104. [CrossRef]

89. Ghanem, N.; Jin, J.I.; Kim, S.S.; Choi, B.H.; Lee, K.L.; Ha, A.N.; Song, S.H.; Kong, I.K. The anti-Müllerian hormone profile is linked with the in vitro embryo production capacity and embryo viability after transfer but cannot predict pregnancy outcome. Reprod. Domest. Anim. 2016, 51, 301-310. [CrossRef]

90. Vernunft, A.; Schwerhoff, M.; Viergutz, T.; Diederich, M.; Kuwer, A. Anti-Muellerian hormone levels in plasma of Holstein-Friesian heifers as a predictive parameter for ovum pick-up and embryo production outcomes. J. Reprod. Dev. 2015, 61, 74-79. [CrossRef]

91. Monniaux, D.; Baril, G.; Laine, A.L.; Jarrier, P.; Poulin, N.; Cognieánd, J.; Fabre, S. Anti-Müllerian hormone as a predictive endocrine marker for embryo production in the goat. Reproduction 2011, 142, 845-854. [CrossRef]

92. Pinto, P.H.N.; Balaro, M.F.A.; Souza-Fabjan, J.M.G.; dos Santos Ribeiro, L.; Bragança, G.M.; Leite, C.R.; Arashiro, E.K.N.; de Moraes Silva, K.; Da Fonseca, J.F.; Brandão, F.Z. Anti-Müllerian hormone and antral follicle count are more effective for selecting ewes with good potential for in vivo embryo production than the presence of FecGE mutation or eCG pre-selection tests. Theriogenology 2018, 113, 146-152.

93. Berry, D.P.; Wall, E.; Pryce, J.E. Genetics and genomics of reproductive performance in dairy and beef cattle. Animal 2014, 8, 105-121. [CrossRef] [PubMed]

94. Nawaz, M.Y.; Jimenez-Krassel, F.; Steibel, J.P.; Lu, Y.; Baktula, A.; Vukasinovic, N.; Neuder, L.; Ireland, J.L.H.; Ireland, J.J.; Tempelman, R.J. Genomic heritability and genome-wide association analysis of anti-Müllerian hormone in Holstein dairy heifers. J. Dairy Sci. 2018, 101, 8063-8075. [CrossRef] [PubMed]

95. Gobikrushanth, M.; Purfield, D.C.; Colazo, M.G.; Butler, S.T.; Wang, Z.; Ambrose, D.J. The relationship between serum anti-Müllerian hormone concentrations and fertility, and genome-wide associations for anti-Müllerian hormone in Holstein cows. J. Dairy Sci. 2018, 101, 7563-7574. [CrossRef] [PubMed] 
96. Walsh, S.W.; Mossa, F.; Butler, S.T.; Berry, D.P.; Scheetz, D.; Jimenez-Krassel, F.; Tempelman, R.J.; Carter, F.; Lonergan, P.; Evans, A.C.O. Heritability and impact of environmental effects during pregnancy on antral follicle count in cattle. J. Dairy Sci. 2014, 97, 4503-4511. [CrossRef] [PubMed]

97. Jaton, C.; Schenkel, F.S.; Sargolzaei, M.; Cánova, A.; Malchiodi, F.; Price, C.A.; Baes, C.; Miglior, F. Genome-wide association study and in silico functional analysis of the number of embryos produced by Holstein donors. J. Dairy Sci. 2018, 101, 7248-7257. [CrossRef] [PubMed]

98. Erickson, B.H. Development and senescence of the postnatal bovine ovary. J. Anim. Sci. 1966, 25, 800-805. [CrossRef] [PubMed]

99. Mossa, F.; Carter, F.; Walsh, S.W.; Kenny, D.A.; Smith, G.W.; Ireland, J.L.H.; Hildebrandt, T.B.; Lonergan, P.; Ireland, J.J.; Evans, A.C.O. Maternal undernutrition in cows impairs ovarian and cardiovascular systems in their offspring. Biol. Reprod. 2013, 88, 1-9, 92. [CrossRef]

100. Sullivan, T.M.; Micke, G.C.; Greer, R.M.; Perry, V.E.A. Dietary manipulation of Bos indicus $\times$ heifers during gestation affects the prepubertal reproductive development of their bull calves. Anim. Reprod. Sci. 2010, 118, 131-139. [CrossRef]

101. Padmanabhan, V.; Veiga-Lopez, A. Reproduction symposium: Developmental programming of reproductive and metabolic health. J. Anim. Sci. 2014, 92, 3199-3210. [CrossRef]

102. El-Sheikh Ali, H.; Kitahara, G.; Nibe, K.; Osawa, T. Endocrinological characterization of an ovarian sex cord-stromal tumor with a Sertoli cell pattern in a Japanese Black cow. Reprod. Domest. Anim. 2019, 54, 1501-1504. [CrossRef]

103. Kitahara, G.; Nambo, Y.; El-Sheikh Ali, H.; Kajisa, M.; Tani, M.; Nibe, K.; Kamimura, S. Anti-Müllerian hormone profiles as a novel biomarker to diagnose granulosa-theca cell tumors in cattle. J. Reprod. Dev. 2012, 58, 98-104. [CrossRef] [PubMed]

104. Ball, B.A.; Almeida, J.; Conley, A.J. Determination of serum anti-Müllerian hormone concentrations for the diagnosis of granulosa-cell tumours in mares. Equine Vet. J. 2013, 45, 199-203. [CrossRef] [PubMed]

105. Almeida, J.; Ball, B.A.; Conley, A.J.; Place, N.J.; Liu, I.K.M.; Scholtz, E.L.; Mathewson, L.; Stanley, S.D.; Moeller, B.C. Biological and clinical significance of anti-Müllerian hormone determination in blood serum of the mare. Theriogenology 2011, 76, 1393-1403. [CrossRef] [PubMed]

106. Walter, B.; Coelfen, A.; Jäger, K.; Reese, S.; Meyer-Lindenberg, A.; Aupperle-Lellbach, H. Anti-Muellerian hormone concentration in bitches with histopathologically diagnosed ovarian tumours and cysts. Reprod. Domest. Anim. 2018, 53, 784-792. [CrossRef] [PubMed]

107. Heaps, L.A.; Scudder, C.J.; Lipscomb, V.J.; Steinbach, S.M.; Priestnall, S.L.; Martineau, H.; Szladovits, B.; Fowkes, R.C.; Garden, O.A. Serum anti-Müllerian hormone concentrations before and after treatment of an ovarian granulosa cell tumour in a cat. J. Feline Med. Surg. Open Rep. 2017, 3, 1-6. [CrossRef] [PubMed]

108. El-Sheikh Ali, H.; Kitahara, G.; Torisu, S.; Nibe, K.; Kaneko, Y.; Hidaka, Y.; Osawa, T. Evidence of spontaneous recovery of granulosa-theca cell tumour in a Heifer: A retrospective report. Reprod. Domest. Anim. 2015, 50, 696-704. [CrossRef]

109. Bungum, L.; Franssohn, F.; Bungum, M.; Humaidan, P.; Giwercman, A. The circadian variation in anti-müllerian hormone in patients with polycystic ovary syndrome differs significantly from normally ovulating women. PLoS ONE 2013, 8, e68223. [CrossRef]

110. Díaz, P.U.; Rey, F.; Gareis, N.C.; Notaro, U.S.; Matiller, V.; Belotti, E.M.; Stassi, A.F.; Salvetti, N.R.; Ortega, H.H. Altered expression of anti-Müllerian hormone during the early stage of bovine persistent ovarian follicles. J. Comp. Pathol. 2018, 158, 22-31. [CrossRef]

111. Caraviello, D.Z.; Weigel, K.A.; Shook, G.E.; Ruegg, P.L. Assessment of the impact of somatic cell count on functional longevity in Holstein and Jersey cattle using survival analysis methodology. J. Dairy Sci. 2005, 88, 804-811. [CrossRef]

(C) 2019 by the authors. Licensee MDPI, Basel, Switzerland. This article is an open access article distributed under the terms and conditions of the Creative Commons Attribution (CC BY) license (http://creativecommons.org/licenses/by/4.0/). 